\title{
Labyrinthe
}

1 | 1998

Numéro 1

\section{Méduse au cinéma}

L'inquiétante étrangeté dans La Belle et la Bête

Cyril Neyrat

\section{(2) OpenEdition}

\section{Journals}

Electronic version

URL: http://journals.openedition.org/labyrinthe/336

DOI: $10.4000 /$ labyrinthe.336

ISSN: 1950-6031

\section{Publisher}

Hermann

\section{Printed version}

Date of publication: 15 October 1998

Number of pages: 63-89

\section{Electronic reference}

Cyril Neyrat, « Méduse au cinéma », Labyrinthe [Online], 1 | 1998, Online since 04 March 2005,

connection on 20 April 2019. URL : http://journals.openedition.org/labyrinthe/336 ; DOI : 10.4000/

labyrinthe.336

This text was automatically generated on 20 April 2019.

Propriété intellectuelle 


\section{Méduse au cinéma}

L'inquiétante étrangeté dans La Belle et la Bête

Cyril Neyrat 